\title{
Frekuensi Asupan Makanan, Pengetahuan Vitamin D dan Obesitas Pada Kelompok Usia Lanjut
}

\section{Food Frequency, Knowledge about Vitamin D and Obesity among Elderly}

\author{
Rivan Virlando Suryadinata ${ }^{1 *}$, Amelia Lorensia $^{2}$
}

\begin{abstract}
ABSTRAK
Latar Belakang: Kelompok usia lanjut di indonesia sebagian besar mengalami defisiensi vitamin D. Pertambahan usia dan penurunan asupan makanan vitamin D akan memicu peningkatan penyakit metabolik. Salah satu dampak penyakit metabolik yang paling sering terjadi adalah obesitas. Pola makan yang tidak sesuai dapat menurunkan konsumsi makanan yang mengandung sumber vitamin $D$. Kesesuaian pola makan dalam mencegah defisiensi vitamin $D$ salah satunya dipengaruhi oleh tingkat pengetahuan mengenai jenis makanan, manfaat dan kebutuhan tubuh akan vitamin D.

Tujuan: Melihat hubungan pola makan dan pengetahuan vitamin D pada usia lanjut dengan obesitas.

Metode: Penelitian ini adalah observational dengan desain case control. Teknik pengumpulan data menggunakan purposive sampling. Sampel pada penelitian ini adalah masyarakat pada usia lanjut dengan obesitas dan non-obesitas. Subjek penelitian pada tiap kelompok berjumlah 88 orang yang memenuhi kriteria inklusi dan eksklusi. Instrumen pada penelitian ini adalah Food Frequency Questionnaire (FFQ) dan kuisioner pengetahun vitamin D berjumlah 11 soal yang telah dilakukan validitas ( $>0,361$ ) dan reliabilitas (Cronbach's Alpha $>0,6$ ). Uji Chi Square digunakan untuk melihat hubungan pola makan vitamin $\mathrm{D}$ dan tingkat pengetahuan pada usia lanjut dengan obesitas dan non-obesitas.

Hasil: Adanya hubungan tingkat pengetahuan dan pola asupan vitamin D pada usia lanjut $(r=0,293 ; p=0,000)$. Namun tidak terdapat perbedaan antara pola asupan dan tingkat pengetahuan terhadap vitamin $D$ pada lansia obesitas dan non obesitas $(p>0,05)$.

Kesimpulan: Peningkatan pengetahuan tentang vitamin D dapat memperbaiki pola asupan makanan pada usia lanjut.
\end{abstract}

Kata Kunci: Usia lanjut, Obesitas, Pengetahuan, Frekuensi Makanan, Vitamin D

\section{ABSTRACT}

Background: Most elderly age groups in Indonesia experience vitamin D deficiency. Increasing age and decreasing food intake of vitamin $D$ will trigger an increase in metabolic diseases. One of the most common effects of metabolic diseases is obesity. Unhealthy diet can reduce consumption of foods that contain sources of vitamin $D$. The suitability of diet in preventing vitamin $D$ deficiency is influenced by the level of knowledge about the type of food, benefits and needs about vitamin D.

Objectives: To analyze the relationship of vitamin D diet in older people with obesity to the level of knowledge of vitamin $D$. Methods: This was analytic observational study with case control design. Data collection technique was using purposive sampling. The sample in this research were geriatric with obesity and non-obesity. Subjects in each group were 88 elderly people according to inclusion and exclusion criteria. Instruments in this research were Food Frequency Questionnaire (FFQ) and questionnaire knowledge of vitamin $D$ amounted to 11 questions that have been done validity ( $r>0.361)$ and reliability (Cronbach's Alpha>0.6). Chi Square test was used to compare age factor with food intake and vitamin D knowledge.

Results: There was significant relationship between the level of knowledge and the pattern of vitamin $D$ intake in old age ( $r$ $=0.293 ; p=0.000$ ). However there was no difference between intake patterns and level of knowledge on vitamin $D$ in elderly obese and non-obese ( $p>0.05)$.

Conclusion: increased in vitamin $D$ knowledge can improve food intake patterns in geriatric.

Keywords : Elderly, Obesity, FFQ, Knowledge, Vitamin D

\footnotetext{
*Koresponden:

Rivan Virlando Suryadinata

rivan.virlando.suryadinata@gmail.com

${ }^{1}$ Fakultas Kedokteran,Universitas Surabaya, Surabaya, Indonesia

2 Fakultas Farmasi, Universitas Surabaya, Surabaya, Indonesia
} 


\section{PENDAHULUAN}

Sebagian besar populasi di dunia mengalami defisiensi vitamin D. Permasalahan ini tidak hanya terjadi pada negara berkembang, tetapi juga pada negara maju. Di Amerika, defisiensi vitamin D mencapai lebih dari 40 $\%$ jumlah penduduknya ${ }^{1}$. Selain itu, beberapa negara seperti China, Afrika dan Timur Tengah juga mengalami defisiensi vitamin D pada berbagai kelompok usia, termasuk wanita hamil dan menyusui, bayi baru lahir, remaja, dan profesional kesehatan. Hal ini memperlihatkan bahwa usia, jenis kelamin, negara asal, dan letak lintang suatu daerah tidak berpengaruh pada kadar vitamin $D$ dalan tubuh ${ }^{2}$. Status vitamin $D$ pada masyarakat dipengaruhi oleh produksi vitamin D3 akibat paparan sinar matahari, asupan makanan atau suplemen. Sebagian besar sumber vitamin D tubuh diperoleh melalui kulit yang terkena paparan sinar matahari, sedangkan sisanya berasal dari asupan makanan $^{3}$.

Vitamin D yang terbentuk melalui sinar matahari berbentuk Vitamin D3 (cholecalciferol) dan disintesis pada tubuh manusia sedangkan vitamin D2 (ergocalciferol) terdapat pada makanan. Sumber asupan utama vitamin $\mathrm{D}$ banyak terdapat pada ikan dan produk olahan susu ${ }^{45}$. Kecukupan vitamin D akan meningkatkan penyerapan kalsium dan fosfor ${ }^{67}$.

Peran vitamin $D$ dalam proses biologis juga cukup penting, walau tidak dibutuhkan dalam jumlah banyak. Status vitamin D yang rendah akan mengganggu respon selular tubuh sehingga dapat menyebabkan peningkatan resiko timbulnya penyakit ${ }^{8}$. Pada usia lanjut hampir $80 \%$ digolongkan defisiensi vitamin D. hal ini berdampak pada berbagai macam penyakit yang ditimbulkan seperti osteomalacia, osteoporosis, penyakit kardioaskular, diabetes tipe 2 , infeksi saluran napas bagian atas dan peningkatan resiko patah tulang. Resiko defisiensi vitamin D pada usia lanjut lebih besar dibandingkan dengan kelompok usia lainnya terutama dikarenakan semakin menurunnya aktivitas fisik dan pola makan yang berkurang ${ }^{9}$. Penurunan aktivitas fisik pada usia lanjut semakin meningkat, bila disertai dengan obesitas. Hal ini dikarenakan pada obesitas terjadi penurunan bioavailibilitas vitamin $D$ dan peningkatan jaringan adiposit ${ }^{10}$.

Peningkatan pengetahuan terhadap pentingnya beraktivitas fisik dan makan makanan yang mengadung vitamin $\mathrm{D}$ akan mempengaruhi jumlah usia lanjut yang mengalami defisiensi vitamin D. Pengetahuan yang kurang tentang pentingnya vitamin $\mathrm{D}$ dalam tubuh akan berbanding lurus dengan sikap yang dilakukan oleh usia lanjut. Pemilihan jenis makanan dan pola asupan yang mengandung vitamin $D$ juga dapat dipengaruhi oleh pengetahuan usia lanjut tentang vitamin $D^{11}$.

\section{METODE}

Penelitian ini termasuk penelitian analitik observational dengan menggunakan Case Control. Penelitian ini dilakukan di poli rawat jalan, Puskesmas Taman, Sidoarjo (No: 070/5099/209.4/2017) pada bulan Mei - Agustus 2017. Populasi yang termasuk dalam penelitian ini adalah masyarakat usia usia lanjut dengan obesitas dan non obesitas di Sidoarjo. Pengambilan sampel dilakukan dengan menggunakan teknik sampling berupa metode purposive sampling, berdasarkan kunjungan pasien usia lanjut yang sesuai dengan kriteria inklusi di Puskemas Taman, Sidoarjo. Besar sampel dalam penelitian ini menggunakan rumus slovin, sehingga ditemukan jumlah sampel minimal adalah 72 $(71,4)$. Namun pada penelitian ini menggunakan 88 orang usia lanjut pada tiap kelompok.

$$
n=\frac{N}{1+N e^{2}}
$$

\section{Keterangan:}

$\mathrm{n}$ = Jumlah sampel penelitian

$\mathrm{N}$ = Jumlah Kunjungan (250)

e $=$ kesalahan yang ditoleransi (10\%)

Penentuan kriteria sampel penelitian dilakukan dengan wawancara identitas diri untuk mengetahui usia responden. Tahap berikutnya dilakukan penimbangan berat badan dan pengukuran tinggi badan untuk memperhitungkan IMT (Indeks Massa Tubuh). Kriteria inklusi dan eksklusi juga menjadi pertimbangan bagi responden penelitian, yaitu memiliki daya ingat yang baik, dapat berkomunikasi dengan lancar serta tidak memiliki penyakit tertentu yang akan mengganggu pola makan responden seperti penyakit diabetes, kardiovaskular, ginjal, dan liver. Selanjutnya responden yang telah memenuhi kriteria akan dibagi menjadi dua kelompok yaitu kelompok usia lanjut obesitas dan non obesitas.

Penelitian ini dilakukan dengan menggunakan instrumen Food Frequency Questionnaire (FFQ) selama 1 bulan terakhir dan kuisioner pengetahuan vitamin $D$ yang telah tervaliditas dan reliabilitas. Sebelumnya, Kuisioner diberikan kepada 30 orang masyarakat dengan tingkat homogenitas yang sama dengan responden penelitian untuk dilakukan uji validitas dan reliabilitas. Setelah kuisioner dinyatakan valid dan reliabel, maka dapat diberikan pada responden penelitian.

Kuisioner yang akan digunakan adalah pengetahuan dan FFQ mengenai vitamin D. Kuisioner pengetahuan vitamin $D$ berisi 11 pertanyaan mengenai pengetahuan terkait paparan sinar matahari terhadap vitamin D. Responden dinyatakan memiliki pengetahuan yang baik apabila jumlah jawaban yang benar adalah 6 atau lebih dari total kuisioner, sedangkan responden yang menjawab benar sebanyak kurang dari 6 total kuisioner pengetahuan akan dikelompokan sebagai pengetahuan kurang. Pembagian kategori pengetahuan baik dan buruk ditentukan berdasarkan nilai median dari responden awal penelitian.

Food Frequency Questionnaire (FFQ) yang digunakan dalam penelitian ini merupakan kuisioner yang telah baku digunakan dan telah mengalami modifikasi pada daftar makanan setelah terlebih dahulu dilakukan studi pendahuluan mengenai kebiasaan dan jenis makanan yang dikonsumsi di wilayah tersebut. Kecukupan asupan vitamin $D$ ditentukan berdasarkan jumlah kebutuhan vitamin D yang dikonsumsi yaitu 400 IU per harinya.

Setelah semua data terkumpul maka akan dilakukan analisis data dengan pengujian Chi-Square antar kelompok untuk melihat perbedaan pengetahuan 
dan frekuensi asupan makanan terhadap usia lanjut obesitas dan non obesitas $(p<0,05)$. Selanjutnya juga dilakukan uji korelasi dengan Spearman untuk melihat adanya hubungan pengetahuan dengan frekuensi

\section{HASIL DAN PEMBAHASAN}

Karateristik responden penelitian disajikan dalam bentuk distribusi frekuensi meliputi jenis kelamin dan usia responden. Berdasarkan tabel 1. penelitian ini menunjukkan sebagian besar responden adalah wanita. Kelompok wanita obesitas berjumlah 70 Orang $(79,54 \%)$ asupan makanan vitamin $D(r<0,05)$. Pengujian statistik dilakukan dengan menggunakan SPSS versi 20. Data penelitian disajikan dengan menggunakan tabel distribusi frekuensi dan tabulasi silang. dan kelompok wanita non obesitas berjumlah 50 orang (56,82\%). Distribusi frekuensi berdasarkan umur pada kelompok obesitas berada pada usia 46-55 tahun $(38,64 \%)$, usia $56-65$ tahun $(43,18 \%)$ dan usia $>65$ tahun $(18,18 \%)$. Sedangkan kelompok non-obesitas berada pada usia $46-55$ tahun $(34,09 \%)$, usia 56-65 tahun (50\%) dan usia $>65$ tahun $(15,91 \%)$.

Tabel 1. Distribusi Frekuensi Karakteristik pada Kelompok Obsitas dan Non-Obesitas

\begin{tabular}{|c|c|c|c|c|c|}
\hline & & \multicolumn{4}{|c|}{ Kelompok } \\
\hline \multicolumn{2}{|c|}{ Karakteristik } & \multicolumn{2}{|c|}{ Obesitas } & \multicolumn{2}{|c|}{ Non-Obesitas } \\
\hline & & $\begin{array}{l}\text { Frekuensi } \\
(\mathrm{n}: 88)\end{array}$ & $\begin{array}{l}\text { Persentase } \\
\text { (\%) }\end{array}$ & $\begin{array}{l}\text { Frekuensi } \\
\text { (n:88) }\end{array}$ & $\begin{array}{c}\text { Persentase } \\
\text { (\%) }\end{array}$ \\
\hline \multirow{2}{*}{ Jenis Kelamin } & Wanita & 70 & 79,54 & 50 & 56,82 \\
\hline & Pria & 18 & 20,45 & 38 & 43,18 \\
\hline \multirow{3}{*}{$\begin{array}{c}\text { Usia } \\
\text { (tahun) }\end{array}$} & $46-55$ & 34 & 38,64 & 30 & 34,09 \\
\hline & $56-65$ & 38 & 43,18 & 44 & 50,00 \\
\hline & $>65$ & 16 & 18.18 & 14 & 15,91 \\
\hline
\end{tabular}

Berdasarkan tabel 2. memperlihatkan adanya hubungan pola makan pada usia lanjut terhadap tingkat pengetahuan vitamin $\mathrm{D}$ pada usia lanjut obesitas dan non obesitas, walaupun hubungan antar keduanya termasuk kategori lemah $(p<0,05 ; \quad r=0,293)$. Pengetahuan vitamin $D$ pada usia lanjut dapat menggambarkan pola konsumsi yang dilakukan sehari hari. Seorang lansia yang mengetahui pentingnya ketersediaan vitamin $D$ pada tubuh, secara tidak langsung akan merubah pola pikir dan perilaku seseorang terkait pola konsumsi ${ }^{1213}$. Walaupun demikian perubahan perilaku pola konsumsi vitamin $D$ pada lansia tidak dapat berdasarkan hanya dengan pengetahuan. Hal tersebut dikarenakan pengetahuan hanya memberikan sebatas pemahaman seseorang terhadap vitamin D. Namun, berbagai faktor juga dapat mempengaruhi pola asupan vitamin D seperti sosial, budaya dan ekonomi yang ada di daeral asalnya ${ }^{14}$.

Tabel 2. Hasil uji Sperman antara asupan makanan dan pengetahuan vitamin D

\begin{tabular}{|c|c|c|c|c|}
\hline \multirow{2}{*}{ Asupan makanan vitamin D } & \multicolumn{2}{|c|}{ Pengetahuan vitamin D } & \multirow{2}{*}{ Total } & \multirow{2}{*}{ Uji Spearman } \\
\hline & Baik & Buruk & & \\
\hline Defisiensi & $\begin{array}{c}85 \\
(48,29 \%) \\
\end{array}$ & $\begin{array}{c}79 \\
(44,89 \%) \\
\end{array}$ & 164 & \multirow{3}{*}{$\begin{array}{c}\text { Nilai } \\
r=0,293 ; \\
p=0,000(p<0,05\end{array}$} \\
\hline Cukup & $\begin{array}{c}10 \\
(5,68 \%)\end{array}$ & $\begin{array}{c}2 \\
(1,14 \%)\end{array}$ & 12 & \\
\hline Total & 95 & 81 & 176 & \\
\hline
\end{tabular}

Berdasarkan tabel 3. penilaian kuisioner asupan makanan vitamin $\mathrm{D}$ sebagian besar tergolong dalam kategori defisiensi pada kelompok obesitas $(90,9 \%)$ dan kelompok non obesitas $(95,45 \%)$. Kelompok obesitas memiliki resiko dua kali lipat menderita defisiensi asupan vitamin $D$ dibandingkan dengan kelompok non obesitas obesitas. Defisiensi Vitamin D tidak dapat dihubungkan secara langsung terhadap terjadinya obesitas, hal ini dikarenakan vitamin $\mathrm{D}$ bukan menjadi faktor utama dan satu-satunya penyebab obesitas. Namun pada beberapa penelitian memperlihatkan penderita obesitas sering memiliki konsentrasi serum $25 \mathrm{D}$ di bawah $50 \mathrm{nmol} / \mathrm{L}^{15}$. Hal tersebut juga dibuktikan dengan pemberian suplemen vitamin $D$ yang dapat menyebabkan penurunan signifikan massa lemak tubuh dibandingkan placebo serta peningkatan kadar serum
25D ${ }^{16}$. Pada usia lanjut penyebab defisiensi vitamin D tidak hanya diakibatkan kurangnya asupan makanan yang dinilai oleh Food Frequency Questionnaire (FFQ) 1718. Berbagai macam faktor dapat berpengaruh terhadap kandungan vitamin D dalam tubuh ${ }^{19}$.

Pada usia lanjut memiliki berbagai permasalahan seperti perubahan fisiologis, perubahan fungsi psikologis, perubahan keadaan sosial, penyakit akut, penyakit kronis dan penggunaan obat-obatan yang dapat mempengaruhi kandungan vitamin $D$ dalam tubuh 20. Hal ini dapat terlihat pada kedua kelompok yang sebagian besar mengalami defisiensi asupan vitamin $\mathrm{D}$. Namun, adanya perubahan fisiologis pada usia lanjut menjadi penyebab utama terjadinya defisiensi vitamin $\mathrm{D}^{21}$. Perubahan fisiologis pada usia lanjut berupa keadaan yang kompleks dengan perubahan terkait 
penuaan yang terjadi pada tingkat struktural, fungsional, dan molekuler dalam tubuh. Hal tersebut dapat memperlambat proses metabolism tubuh dan memicu terjadinya obesitas ${ }^{22}$. Selain itu, proses penuaan yang dapat mengganggu nafsu makan secara fisiologis meliputi perubahan pada sistem pencernaan, perubahan hormonal, penyakit, rasa sakit, perubahan rasa penciuman, rasa dan penglihatan serta penurunan kebutuhan akan energi ${ }^{20}$. Penurunan daya tahan tubuh akan meningkatan radikal bebas dari spesies oksigen reaktif yang dihasilkan oleh mitokondria, sehingga dapat menyebabkan kerusakan oksidatif pada DNA, protein, dan lipid ${ }^{2223}$. perubahan pada sistem pencernaan pada usia lanjut meliputi adanya penurunan kontraksi esofagus dan penurunan peristaltik yang terjadi saat proses menelan, pengosongan lambung yang dua kali lebih lama dari usia remaja, sekresi asam lambung dan penyerapan nutrisi yang berkurang ${ }^{24}$.

Tabel 3. Distribusi frekuensi asupan makanan vitamin D pada kelompok obesitas dan non obesitas

\begin{tabular}{|c|c|c|c|c|c|c|c|}
\hline \multirow{3}{*}{\multicolumn{2}{|c|}{$\begin{array}{l}\text { Asupan makanan } \\
\text { vitamin D }\end{array}$}} & \multicolumn{4}{|c|}{ Kelompok } & \multirow{3}{*}{ P Value } & \multirow{3}{*}{ OR } \\
\hline & & \multicolumn{2}{|c|}{ Obesitas (n:88) } & \multicolumn{2}{|c|}{ Non Obesitas ( $\mathrm{n}: 88$ ) } & & \\
\hline & & Frekuensi & $\begin{array}{c}\text { Presentase } \\
\text { (\%) }\end{array}$ & Frekuensi & $\begin{array}{c}\text { Presentase } \\
\text { (\%) }\end{array}$ & & \\
\hline \multirow{2}{*}{ Kategori } & Defisiensi & 80 & 90,9 & 84 & 95,45 & \multirow{3}{*}{0,232} & \multirow{3}{*}{0,48} \\
\hline & Cukup & 8 & 9,1 & 4 & 4,55 & & \\
\hline \multicolumn{2}{|c|}{ Total } & 88 & 100 & 88 & 100 & & \\
\hline
\end{tabular}

Perubahan psikososial diperkirakan juga berperan menyebabkan gangguan asupan makanan pada usia lanjut. Penyebab utama perubahan psikologi adalah depresi, yang diperkirakan hampir $25 \%$ usia lanjut yang mengalami hal tersebut ${ }^{25}$. Dampak psikososial lainnya adalah sebagian usia lanjut hidup sendiri dan malu untuk bersosialisasi, sehingga dapat menurunkan semangat untuk berinteraksi dan melakukan kegiatan seperti berbelanja, mengolah makanan, memasak serta makan ${ }^{26}$. Beberapa penyakit pada usia lanjut seperti delirium dan penggunaan obat-obatan juga dapat mengubah rasa dan bau, sehingga menimbulkan rasa mual yang dapat mengurangi napsu makan 27. Sedangkan, pengaruh obesitas pada usia lanjut terkait dengan pola makan yang tidak teratur dan terkontrol, aktivitas fisik, pola tidur, genetik serta lingkungan ${ }^{282930}$. Berbagai macam pengaruh yang mengakibatkan peningkatan konsumsi pada usia lanjut akan berdampak terjadinya penambahan berat badan, namun hal tersebut tidak memberikan pengaruh terhadap kecukupan vitamin $D^{31}$.

Tabel 4. Distribusi frekuensi pengetahuan vitamin D pada kelompok obesitas dan non obesitas

\begin{tabular}{|c|c|c|c|c|c|c|c|}
\hline \multirow{3}{*}{\multicolumn{2}{|c|}{$\begin{array}{l}\text { Pengetahuan } \\
\text { Vitamin D }\end{array}$}} & \multicolumn{4}{|c|}{ Kelompok } & \multirow{3}{*}{ P Value } & \multirow{3}{*}{ OR } \\
\hline & & \multicolumn{2}{|c|}{ Obesitas (n:88) } & \multicolumn{2}{|c|}{ Non Obesitas ( $\mathrm{n}: 88$ ) } & & \\
\hline & & Frekuensi & $\begin{array}{c}\text { Presentase } \\
\text { (\%) }\end{array}$ & Frekuensi & $\begin{array}{c}\text { Presentase } \\
\text { (\%) }\end{array}$ & & \\
\hline \multirow{2}{*}{ Kategori } & Baik & 51 & 57,95 & 44 & 50 & \multirow{3}{*}{0,290} & \multirow{3}{*}{0,73} \\
\hline & Buruk & 37 & 42,05 & 44 & 50 & & \\
\hline \multicolumn{2}{|c|}{ Total } & 88 & 100 & 88 & 100 & & \\
\hline
\end{tabular}

Pada table 4. menunjukkan penilaian pengetahuan vitamin $\mathrm{D}$ pada kelompok usia lanjut obesitas dan non obesitas. Pada kelompok usia lanjut obesitas didapatkan 51 orang $(57,95 \%)$ memiliki pengetahuan baik dan 37 orang $(42,05 \%)$ memiliki pengetahuan buruk, sedangkan pada kelompok usia lanjut non obesitas didapatkan 44 orang (50\%) pengetahuan baik dan 44 orang $(50 \%)$ pengetahuan buruk. Kelompok usia lanjut dengan obesitas memiliki pengetahuan 1,5 kali lebih terhadap vitamin D dibandingkan dengan kelompok usia lanjut non obesitas.

\section{KESIMPULAN}

Kelompok usia lanjut dengan obesitas lebih beresiko untuk menderita defisiensi vitamin $D$, walaupun sebagian besar memiliki tingkat pengetahuan yang lebih baik dibandingkan dengan kelompok usia lanjut non obesitas.

\section{ACKNOWLEDGEMENT}

Terima kasih disampaikan kepada Puskesmas Taman, Sidoarjo, Jawa Timur yang telah memberikan kesempatan untuk melakukan pengambilan data. 


\section{REFERENSI}

1. Forrest, K. Y. Z. \& Stuhldreher, W. L. Prevalence and correlates of vitamin $D$ deficiency in US adults. Nutr. Res. 31, 48-54 (2011).

2. Gupta, P. \& Shah, D. Vitamin D deficiency: Is the pandemic for real? Indian J. Community Med. 40, 215 (2015).

3. Lips, P. Worldwide status of vitamin D nutrition J. Steroid Biochem. Mol. Biol. 121, 297-300 (2010).

4. Papandreou, D. \& Hamid, Z. T. N. The Role of Vitamin D in Diabetes and Cardiovascular Disease: An Updated Review of the Literature. Dis. Markers 2015, (2015).

5. Holick, M. F. et al. Evaluation, Treatment, and Prevention of Vitamin D Deficiency: an Endocrine Society Clinical Practice Guideline. J. Clin. Endocrinol. Metab. 96, 1911-1930 (2011).

6. Nair, R. \& Maseeh, A. Vitamin D: The 'sunshine' vitamin. J. Pharmacol. Pharmacother. 3, 118-26 (2012).

7. Suryadinata, R. V., Lorensia, A. \& Aprilia, A. P. Profil Vitamin D Pada Pasien Asma dan NonAsma Dewasa di Surabaya. Indones. J. Public Heal. 12, 106 (2017).

8. Baggerly, C. A. et al. Sunlight and Vitamin D: Necessary for Public Health. J. Am. Coll. Nutr. 34, 359-365 (2015).

9. Annweiler, C. et al. Self-administered Vitamin D Status Predictor: Older adults are able to use a self-questionnaire for evaluating their vitamin $D$ status. PLoS One 12, e0186578 (2017).

10. Daniel, D., Hardigan, P., Bray, N., Penzell, D. \& Savu, C. The incidence of vitamin D deficiency in the obese: a retrospective chart review. J. Community Hosp. Intern. Med. Perspect. 5, 26069 (2015).

11. Aljefree, N. M., Lee, P. \& Ahmed, F. Knowledge and attitudes about vitamin $D$, and behaviors related to vitamin $D$ in adults with and without coronary heart disease in Saudi Arabia. BMC Public Health 17, 266 (2017).

12. Faronbi, J. O., Adebowale, O., Faronbi, G. O., Musa, O. O. \& Ayamolowo, S. J. Perception knowledge and attitude of nursing students towards the care of older patients. Int. J. Africa Nurs. Sci. 7, 37-42 (2017).

13. Suryadinata, R. V., Wirjatmadi, B., Adriani, M. \& Sumarmi, S. Effects of knowledge of vitamin D on attitudes toward sun exposure among middle-aged and elderly Indonesian adults. Indian J. Public Heal. Res. Dev. 9, (2018).

14. Nemeth, N., Rudnak, I., Ymeri, P. \& Fogarassy, C. The Role of Cultural Factors in Sustainable Food Consumption-An Investigation of the Consumption Habits among International Students in Hungary. Sustainability 11, 3052 (2019).

15. Vanlint, S. Vitamin D and Obesity. Nutrients 5, 949-956 (2013).

16. Salehpour, A. et al. A 12-week double-blind randomized clinical trial of vitamin D3supplementation on body fat mass in healthy overweight and obese women. Nutr. J. 11, 78 (2012).

17. Sauvageot, N., Alkerwi, A., Albert, A. \& Guillaume, M. Use of food frequency questionnaire to assess relationships between dietary habits and cardiovascular risk factors in NESCAV study: validation with biomarkers.

Nutr. J. 12, 143 (2013).

18. Pratiwi, S. R., Lorensia, A. \& Suryadinata, R. V. Asupan Vitamin C dan E Dengan SQ-FFQ terhadap Fungsi Paru Perokok dan NonPerokok. Media Kesehat. Masy. Indones. 14, 101 (2018).

19. Moghames, P. et al. Validity and reliability of a food frequency questionnaire to estimate dietary intake among Lebanese children. Nutr. J. 15, 4 (2015).

20. Pilgrim, A. L., Robinson, S. M., Sayer, A. A. \& Roberts, H. C. An overview of appetite decline in older people. Nurs. Older People 27, 29-35 (2015).

21. Suryadinata, R. V., Lorensia, A. \& Tangkilisan, E. C. Effect of Physical Activity and Vitamin D Status on Geriatrics Obesity. Glob. Med. Heal. Commun. 7, 1-6 (2019).

22. Starr, K. N. P., McDonald, S. R. \& Bales, C. W. Nutritional Vulnerability in Older Adults: A Continuum of Concerns. Curr. Nutr. Rep. 4, 176184 (2015).

23. Suryadinata, R. V., Wirjatmadi, B. \& Adriani, M. Effectiveness Decrease Combined with Supplements Malondialdehyde Antioxidant Superoxide Dismutase Gliadin Melon with Due to Exposure to Cigarette. Glob. Med. Heal. Commun. 5, 79-83 (2017).

24. Alvis, B. D. \& Hughes, C. G. Physiology Considerations in Geriatric Patients. Anesthesiol. Clin. 33, 447-456 (2015).

25. Engel, J. H. et al. Hardiness, Depression, and Emotional Well-Being and Their Association with Appetite in Older Adults. J. Am. Geriatr. Soc. 59, 482-487 (2011).

26. Age UK. Later life in the United Kingdom. Factsheet April (2018). doi:10.1016/j.egypro.2016.11.209

27. Mudge, A. M., Ross, L. J., Young, A. M., Isenring E. A. \& Banks, M. D. Helping understand nutritional gaps in the elderly (HUNGER): A prospective study of patient factors associated with inadequate nutritional intake in older medical inpatients. Clin. Nutr. 30, 320-325 (2011).

28. Hruby, A. et al. Detdf

erminants and Consequences of Obesity. Am. J. Public Health 106, 1656-1662 (2016).

29. Suryadinata, R. V., Lorensia, A. \& Sari, R. K. Differences in Nutrition Food Intake and Body Mass Index between Smoker and Non-smoker 
in Adult. Indones. J. Clin. Pharm. 6, 171-180 (2017).

30. Indraswari, P. I. I., Lorensia, A. \& Suryadinata, R. V. Analysis Effect of Nutrition Intake on Lung Function of Active Smoker and Non Smoker. J. Kesehat. Masy. 14, 247-253 (2018).

31. Suryadinata, R. V. \& Sukarno, D. A. The Effect of Physical Activity on The Risk of Obesity in Adulthood. Indones. J. Public Heal. 14, 104 (2019). 


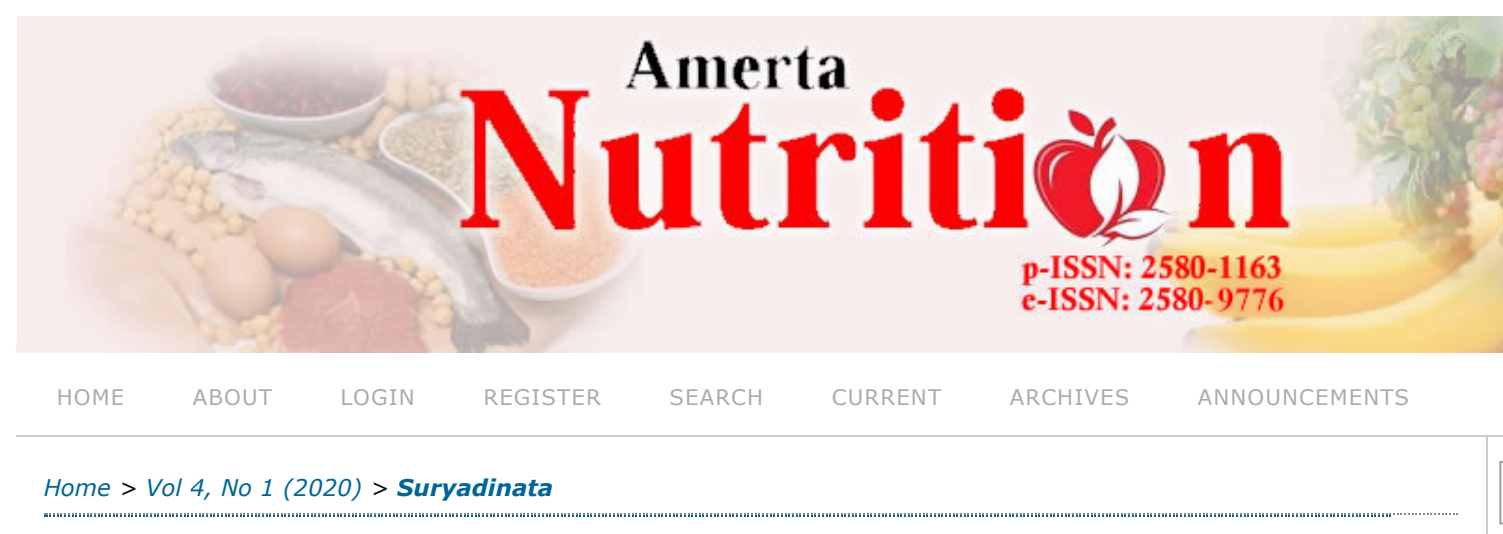

National Accreditation

\section{FREKUENSI ASUPAN MAKANAN, PENGETAHUAN VITAMIN D DAN OBESITAS PADA KELOMPOK USIA LANJUT}

3 Rivan Virlando Suryadinata, Amelia Lorensia

doi = http://dx.doi.org/10.20473/amnt.v4i1.2020.43-48

爪I Abstract views $=131$ times

\section{ABSTRACT}

Background: Most elderly age groups in Indonesia experience vitamin D deficiency. Increasing age and decreasing food intake of vitamin D will trigger an increase in metabolic diseases. One of the most common effects of metabolic diseases is obesity. Unhealthy diet can reduce consumption of foods that contain sources of vitamin D. The suitability of diet in preventing vitamin D deficiency is influenced by the level of knowledge about the type of food, benefits and needs about vitamin D. Objectives: To analyze the relationship of vitamin $D$ diet in older people with obesity to the level of knowledge of vitamin D.Methods: This was analytic observational study with case control design. Data collection technique was using purposive sampling. The sample in this research were geriatric with obesity and non-obesity. Subjects in each group were 88 elderly people according to inclusion and exclusion criteria. Instruments in this research were Food Frequency Questionnaire (FFQ) and questionnaire knowledge of vitamin D amounted to 11 questions that have been done validity ( $r>0.361$ ) and reliability (Cronbach's Alpha> 0.6). Chi Square test was used to compare age factor with food intake and vitamin $D$ knowledge. Results: There was significant relationship between the level of knowledge and the pattern of vitamin $D$ intake in old age $(r=0.293 ; p=0.000)$. However there was no difference between intake patterns and level of knowledge on vitamin $D$ in elderly obese and non-obese $(p>$ 0.05).

Conclusion: increased in vitamin D knowledge can improve food intake patterns in geriatric.

\section{ABSTRAK}

Latar Belakang: Kelompok usia lanjut di indonesia sebagian besar mengalami defisiensi vitamin D. Pertambahan usia dan penurunan asupan makanan vitamin D akan memicu peningkatan penyakit metabolik. Salah satu dampak penyakit metabolik yang paling sering terjadi adalah obesitas. Pola makan yang tidak sesuai dapat menurunkan konsumsi makanan yang mengandung sumber vitamin D. Kesesuaian pola makan dalam mencegah defisiensi vitamin D salah satunya dipengaruhi oleh tingkat pengetahuan mengenai jenis makanan, manfaat dan kebutuhan tubuh akan vitamin D.

Tujuan: Melihat hubungan pola makan dan pengetahuan vitamin D pada usia lanjut dengan obesitas.

Metode: Penelitian ini adalah observational dengan desain case control. Teknik pengumpulan data menggunakan purposive sampling. Sampel pada penelitian ini adalah masyarakat pada usia lanjut dengan obesitas dan non-obesitas. Subjek penelitian pada tiap kelompok berjumlah 88 orang yang memenuhi kriteria inklusi dan eksklusi. Instrumen pada penelitian ini adalah Food Frequency Questionnaire (FFQ) dan kuisioner pengetahun vitamin D berjumlah 11 soal yang telah dilakukan validitas ( $r>0,361)$ dan reliabilitas (Cronbach's Alpha > 0,6). Uji Chi Square digunakan untuk melihat hubungan pola makan vitamin D dan tingkat pengetahuan pada usia lanjut dengan obesitas dan non-obesitas.

Hasil: Adanya hubungan tingkat pengetahuan dan pola asupan vitamin $D$ pada usia lanjut $(r=0,293 ; p=0,000)$. Namun tidak terdapat perbedaan antara pola asupan dan tingkat pengetahuan terhadap vitamin $D$ pada lansia obesitas dan non obesitas ( $p>0,05)$.

Kesimpulan: Peningkatan pengetahuan tentang vitamin D dapat memperbaiki pola asupan makanan pada usia lanjut.

\section{KEYWORDS}

Elderly, Obesity, FFQ, Knowledge, Vitamin D

\section{FULL TEXT:}

밀 PDF

\section{REFERENCES}

Forrest, K. Y. Z. \& Stuhldreher, W. L. Prevalence and correlates of vitamin D deficiency in US adults. Nutr. Res. 31, 48-54 (2011).

Gupta, P. \& Shah, D. Vitamin D deficiency: Is the pandemic for real? Indian J. Community Med. 40, 215 (2015).

\section{Csîta2}

Download
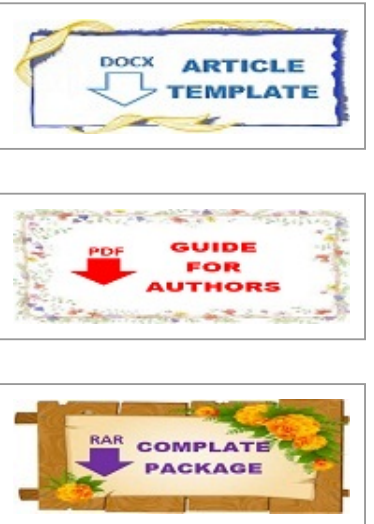

Instruction for Author

Guide for authors

Online Submission

Download Documents

\section{People}

Editorial Team

Peer Reviewers

Contact

Joumal Policy

Focus and Scope

Publication Ethics

Article Processing Charge

Peer Reviewers Process

Open Access Statement

Archiving

Plagiarism

Indexing

History

Copyright

Articles Cited in

\section{Scopus}

Lips, P. Worldwide status of vitamin D nutrition. J. Steroid Biochem. Mol. Biol. 121, 297-300 (2010). 
Papandreou, D. \& Hamid, Z. T. N. The Role of Vitamin D in Diabetes and Cardiovascular Disease: An Updated Review of the Literature. Dis. Markers 2015, (2015).

Holick, M. F. et al. Evaluation, Treatment, and Prevention of Vitamin D Deficiency: an Endocrine Society Clinical Practice Guideline. J. Clin. Endocrinol. Metab. 96, 1911-1930 (2011).

Nair, R. \& Maseeh, A. Vitamin D: The 'sunshine' vitamin. J. Pharmacol. Pharmacother. 3, 118-26 (2012).

Suryadinata, R. V., Lorensia, A. \& Aprilia, A. P. Profil Vitamin D Pada Pasien Asma dan Non-Asma Dewasa di Surabaya. Indones. J. Public Heal. 12, 106 (2017).

Baggerly, C. A. et al. Sunlight and Vitamin D: Necessary for Public Health. J. Am. Coll. Nutr. 34, 359-365 (2015).

Annweiler, C. et al. Self-administered Vitamin D Status Predictor: Older adults are able to use a selfquestionnaire for evaluating their vitamin D status. PLoS One 12, e0186578 (2017).

Daniel, D., Hardigan, P., Bray, N., Penzell, D. \& Savu, C. The incidence of vitamin D deficiency in the obese: a retrospective chart review. J. Community Hosp. Intern. Med. Perspect. 5, 26069 (2015).

Aljefree, N. M., Lee, P. \& Ahmed, F. Knowledge and attitudes about vitamin D, and behaviors related to vitamin $\mathrm{D}$ in adults with and without coronary heart disease in Saudi Arabia. BMC Public Health 17, 266 (2017).

Faronbi, J. O., Adebowale, O., Faronbi, G. O., Musa, O. O. \& Ayamolowo, S. J. Perception knowledge and attitude of nursing students towards the care of older patients. Int. J. Africa Nurs. Sci. 7, 37-42 (2017).

Suryadinata, R. V., Wirjatmadi, B., Adriani, M. \& Sumarmi, S. Effects of knowledge of vitamin D on attitudes toward sun exposure among middle-aged and elderly Indonesian adults. Indian J. Public Heal. Res. Dev. 9, (2018).

Nemeth, N., Rudnak, I., Ymeri, P. \& Fogarassy, C. The Role of Cultural Factors in Sustainable Food Consumption -An Investigation of the Consumption Habits among International Students in Hungary. Sustainability 11, 3052 (2019).

Vanlint, S. Vitamin D and Obesity. Nutrients 5, 949-956 (2013).

Salehpour, A. et al. A 12-week double-blind randomized clinical trial of vitamin D3supplementation on body fat mass in healthy overweight and obese women. Nutr. J. 11, 78 (2012).

Sauvageot, N., Alkerwi, A., Albert, A. \& Guillaume, M. Use of food frequency questionnaire to assess relationships between dietary habits and cardiovascular risk factors in NESCAV study: validation with biomarkers. Nutr. J. 12, 143 (2013).

Pratiwi, S. R., Lorensia, A. \& Suryadinata, R. V. Asupan Vitamin C dan E Dengan SQ-FFQ terhadap Fungsi Paru Perokok dan Non-Perokok. Media Kesehat. Masy. Indones. 14, 101 (2018).

Moghames, P. et al. Validity and reliability of a food frequency questionnaire to estimate dietary intake among Lebanese children. Nutr. J. 15, 4 (2015).

Pilgrim, A. L., Robinson, S. M., Sayer, A. A. \& Roberts, H. C. An overview of appetite decline in older people. Nurs. Older People 27, 29-35 (2015).

Suryadinata, R. V., Lorensia, A. \& Tangkilisan, E. C. Effect of Physical Activity and Vitamin D Status on Geriatrics Obesity. Glob. Med. Heal. Commun. 7, 1-6 (2019).

Starr, K. N. P., McDonald, S. R. \& Bales, C. W. Nutritional Vulnerability in Older Adults: A Continuum of Concerns. Curr. Nutr. Rep. 4, 176-184 (2015).

Suryadinata, R. V., Wirjatmadi, B. \& Adriani, M. Effectiveness Decrease Combined with Supplements Malondialdehyde Antioxidant Superoxide Dismutase Gliadin Melon with Due to Exposure to Cigarette. Glob. Med. Heal. Commun. 5, 79-83 (2017).

Alvis, B. D. \& Hughes, C. G. Physiology Considerations in Geriatric Patients. Anesthesiol. Clin. 33, 447-456 (2015).

Engel, J. H. et al. Hardiness, Depression, and Emotional Well-Being and Their Association with Appetite in Older Adults. J. Am. Geriatr. Soc. 59, 482-487 (2011).

Age UK. Later life in the United Kingdom. Factsheet April (2018). doi:10.1016/j.egypro.2016.11.209

Mudge, A. M., Ross, L. J., Young, A. M., Isenring, E. A. \& Banks, M. D. Helping understand nutritional gaps in the elderly (HUNGER): A prospective study of patient factors associated with inadequate nutritional intake in older medical inpatients. Clin. Nutr. 30, 320-325 (2011).

Hruby, A. et al. Detdf

erminants and Consequences of Obesity. Am. J. Public Health 106, 1656-1662 (2016).

Suryadinata, R. V., Lorensia, A. \& Sari, R. K. Differences in Nutrition Food Intake and Body Mass Index between Smoker and Non-smoker in Adult. Indones. J. Clin. Pharm. 6, 171-180 (2017).

Indraswari, P. I. I., Lorensia, A. \& Suryadinata, R. V. Analysis Effect of Nutrition Intake on Lung Function of Active Smoker and Non Smoker. J. Kesehat. Masy. 14, 247-253 (2018).

Suryadinata, R. V. \& Sukarno, D. A. The Effect of Physical Activity on The Risk of Obesity in Adulthood. Indones. J. Public Heal. 14, 104 (2019).

\section{REFBACKS}

- There are currently no refbacks.

\section{USER}

Username amelialorensia

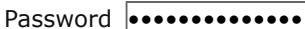

Remember me

Login

\section{ARTICLE TOOLS}

Print this article

Indexing metadata

How to cite item

Finding References

Email this article (Login required)

Email the author (Login required)

\section{NOTIFICATIONS}

View

Subscribe

TOOLS:

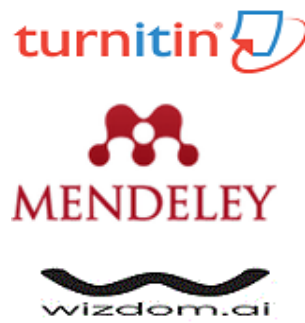

in collaboration with:

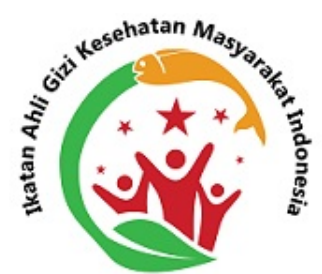

\section{LISTED in:}

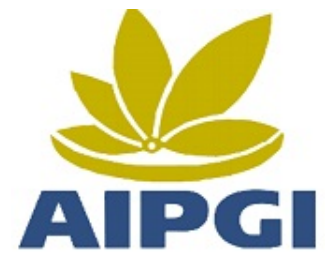

publons

4.6. ICM|E E

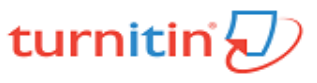

JOURNAL CONTENT

Search

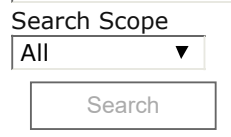


p-ISSN : 2580-1163

e-ISSN : 2580-9776

\section{2}

AmertaNutr

INDEXING BY:

$\square \leadsto \begin{aligned} & \text { DIRECTORY OF } \\ & \text { OPEN ACCESS } \\ & \text { JOURNALS }\end{aligned}$ Sîtata EBSCO $\begin{aligned} & \text { INFORMATION } \\ & \text { SERVICES }\end{aligned}$

\section{Google [Basa crossef Si WorldCat Hinari}

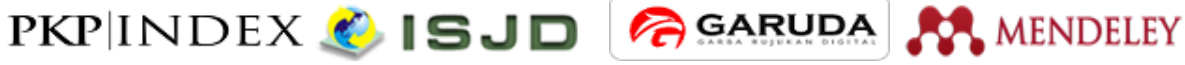

\section{ROAD@Scilit JournalTocs @ C CNKI}

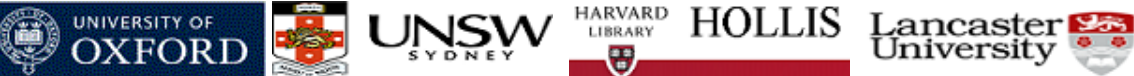

Boston University Libraries 1. Universiteit

Open BU

Browse

By Issue

By Author

By Title

Other Journals

\section{ABOUT THE AUTHORS}

Rivan Virlando Suryadinata

Universitas Surabaya

Indonesia

Departemen Kesehatan

Masyarakat

\section{Amelia Lorensia}

Universitas Surabaya

\section{KEYWORDS}

amino acid, citrulline, sport nutrition, sport performance, athletes anemia anemia, enhancer, inhibitor, zat besi attitude children children, nutrient intake, stunting dietary diversity

energy intake food intake, weekend, weekday, obesity free radical, COPD, inflammation, cigarette smoke hemoglobin level infectious disease knowledge mother's knowledge,

mother's education, exclusive

months nutritional status personal education, lecture, knowledg

facts label protein intake

stunting toddler underweight zinc 


\section{Amerta

\section{EDITORIAL TEAM}

\section{EDITOR IN CHIEF}

Trias Mahmudiono S.KM., M.PH (Nutr), GCAS., Ph.D, (SCOPUS ID: 57189899256), Department of Health Nutrition, Faculty of Public Health, Universitas Airlangga, Indonesia

\section{EDITORIAL BOARD}

Prof. Roger Hughes MPH, Ph.D, (SCOPUS ID: 7404299920), Public Health and Health Systems, University of Tasmania, Australia

Prof. Jörg-Ingolf Stein, (SCOPUS ID : 6504189694), Department of Pediatrics III, Medizinische Universität Innsbruck, Austria

Assoc. Prof. Hazreen Bin Abdul Majid, Bsc Dietetic. M Nut Dietetic, Ph. D (SCOPUS ID: 54893067500 ),

Department Social and Preventive Medicine, Faculty of Medicine, University of Malaya, Malaysia

Assoc. Prof. Wantanee Kriengsinyos, Ph.D., RD, (SCOPUS ID: 6506938692), Human Nutrition Division, Institute of Nutrition, Mahidol University, Thailand

Associate Professor. C.A. Kalpana, M.Sc., Bed., M.Phil., PhD, Avinashilingam Institute for Home Science and Higher Education for Women, India

Dr. Beben Benyamin, (RESEARCHER ID: D-9195-2012; SCOPUS ID: 16314927500), Biostatistics School of Health Sciences, University of South Australia, Australia

Febi Dwirahmadi, S.KM., M.PH., Ph.D, (SCOPUS ID: 55900228400), Centre for Environment and Population Health, Griffith School of Environment, Nathan Campus, Brisbane, Queensland, Australia

Dr. Luh Ade Ari Wiradnyani, M.Sc, (SCOPUS ID: 57079273000), SEAMEO Regional Center for Food and Nutrition, Indonesia

Susy Katikana Sebayang, SP., M.Sc, Ph.D, (SCOPUS ID: 24068188900), Department of Biostatistic and

Populations, Faculty of Public Health, PDD Banyuwangi, Universitas Airlangga, Indonesia

Agung Dwi Laksono, S.KM, M.Kes, (SCOPUS ID: 56429657100), Center for Humanities, Health Policy, and

Community Empowerment Research and Development Agency, Ministry of Health of the Republic of Indonesia. Indonesia

Dr. dr. Sri Adiningsih, MS., MCN, The National Sports Committee of Indonesia, East Java Province, Indonesia Dr. Farida Wahyu Ningtyas, S.KM, M.Kes, Department of Health Nutrition, Faculty of Public Health, University of Jember, Indonesia

\section{MANAGING EDITOR}

Farapti dr., M.Gizi, (SCOPUS ID: 57196396416), Indonesian Medical Association, East Java Province, Indonesia Mahmud Aditya Rifqi, S.Gz, M.Si, Department of Health Nutrition, Faculty of Public health, Universitas Airlangga, Indonesia, Indonesia

Emalia Rhitmayanti, S.Gz, MP, Association of Food and Nutrition Experts, Indonesia

Dina Rahayuning Pangestuti, STP., M.Gizi, (SCOPUS ID: 57192903853), Faculty of Public Health, Universitas Diponegoro, Indonesia

\section{EDITORIAL ASSISTANT}

Diyah Alinia Oktariningtias, S.KM, Faculty of Public Health, Universitas Airlangga, Indonesia Asri Yanuarista, Amd, Faculty of Science and Technology, Universitas Airlangga, Indonesia

\section{(c) (i) (2)}

AMERTA NUTR by Unair is licensed under a Creative Commons Attribution-ShareAlike 4.0 International License.

p-ISSN : 2580-1163

e-ISSN : 2580-9776

00241256

AmertaNutr

INDEXING BY:

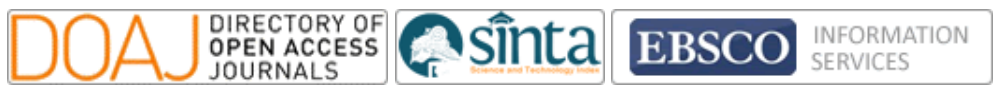

\section{Cînta2}

\section{Download}

DOCX ARTICLE TEMPLATE

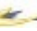

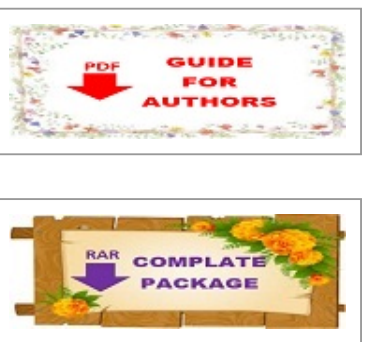

Instruction for Author

Guide for authors

Online Submission

Download Documents

\section{People}

Editorial Team

Peer Reviewers

Contact

\begin{tabular}{l} 
Journal Policy \\
\hline Focus and Scope \\
\hline Publication Ethics \\
Article Processing Charge \\
\hline Peer Reviewers Process \\
Open Access Statement \\
Archiving \\
\hline Plagiarism \\
Indexing \\
History \\
Copyright
\end{tabular}

Articles Cited in

\section{Scopus}


Google YaAsE crossref STWorldCat Hinart PKP|INDEX IS DI CARARA RӘAD (10) Scilit JournalTOCs

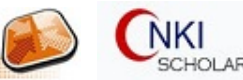
UNIVESSTYY OF ONSWW

Boston University Libraries OpenBU

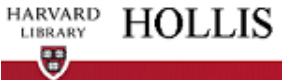
장

A. Universiteit Wide Leiden Catalogue

\section{Lancaster} University
TOOLS:
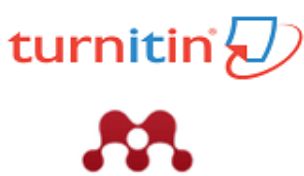

MENDELEY

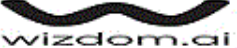

in collaboration with:

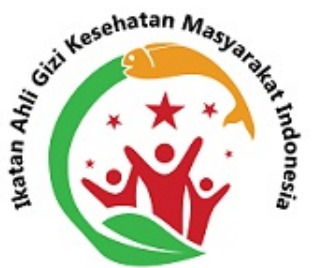

\section{LISTED in:}

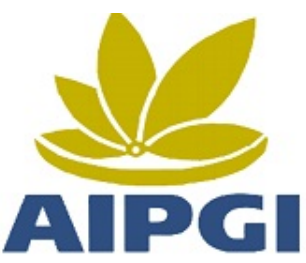

\section{publons}

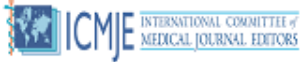
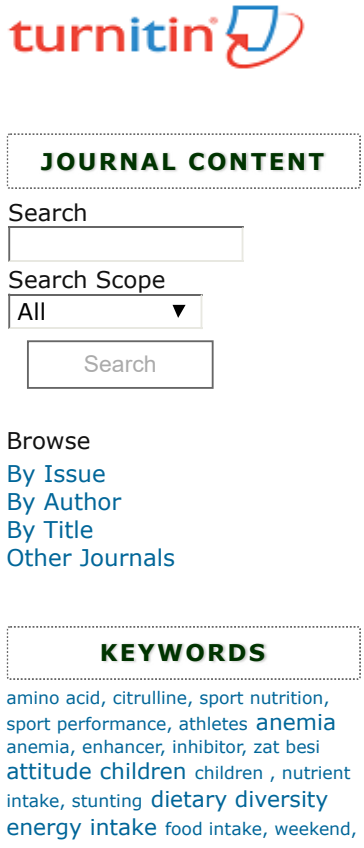
weekday, obesity free radical, COPD, inflammation, cigarette smoke hemoglobin level infectious disease knowledge mother's knowledge,

mother's education, exclusive
breastfeeding, infants aged 6-12

months nutritional status personal education, lecture, knowledg facts label protein intake stunting toddler underweight zinc

Pusat Pengembangan Jurnal dan Publikasi IImiah

Universitas Airlangga

copyright@2017 Template PPJPI 


\section{Amerta

\section{TABLE OF CONTENTS}

\section{ARTICLES}

Analisis Kesesuaian Kandungan Energi dan Zat Gizi Makro Rencana Menu dengan Standar Diet untuk Pasien Diabetes Mellitus

doi 10.20473 /amnt.v4i1.2020.1-7

Afifah Yasyfa Dhiyanti, Laksmi Karunia Tanuwijaya, Eva Putri Arfiani

Hubungan Sulit Makan Pangan Hewani, Tingkat Asupan Energi, Asam Folat, dan Seng dengan Perkembangan Motorik Halus dan Motorik Kasar Anak Prasekolah di TK Kristen Setabelan Surakarta

d.

10.20473/amnt.v4i1.2020.8-12

Hana Dwi Prastika, Sri Sumarmi

Hubungan Karakteristik Santri, Mutu Makanan, dan Daya Terima Konsumsi Santri Di SMA Al Izzah International Islamic Boarding School Kota Batu

d.

10.20473/amnt.v4i1.2020.13-22

Syahida IIma Amalia

Hubungan Tingkat Kecukupan Karbohidrat Dan Persen Lemak Tubuh Dengan Sindroma Pramenstruasi (PMS) Pada Remaja Putri

d.

10.20473/amnt.v4i1.2020.23-29

Shella Habibatul Illah Rahmadianta, Sri Adiningsih

Hubungan ASI Eksklusif dan Frekuensi Sakit Pada Bayi di Surabaya Barat

doi 10.20473/amnt.v4i1.2020.30-35

Dianatul Fitri, Dian Shofiya

Perbedaan Gejala pada Anak Autis yang Diet Bebas Gluten dan Kasein dengan yang Tidak Diet di Surabaya

10.20473/amnt.v4i1.2020.36-42

Alifah Fajriyyatul Izzah, Widati Fatmaningrum, Roedi Irawan

Frekuensi Asupan Makanan, Pengetahuan Vitamin D dan Obesitas Pada Kelompok Usia Lanjut

doi

10.20473/amnt.v4i1.2020.43-48

Rivan Virlando Suryadinata, Amelia Lorensia

Perbedaan Pola Asuh dan Tingkat Kecukupan Zat Gizi pada Balita Stunting dan NonStunting di Wilayah Pesisir Kabupaten Probolinggo

doi

10.20473/amnt.v4i1.2020.49-57

Mita Femidio, Lailatul Muniroh \\ $1-7$}
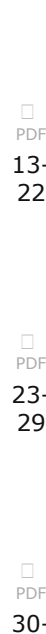

\section{Download}
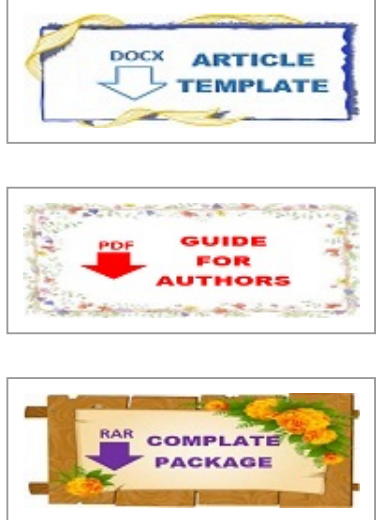

Instruction for Author

Guide for authors

Online Submission

Download Documents

\section{People}

Editorial Team

Peer Reviewers

Contact

\begin{tabular}{l} 
Journal Policy \\
\hline Focus and Scope \\
Publication Ethics \\
Article Processing Charge \\
\hline Peer Reviewers Process \\
Open Access Statement \\
\hline Archiving \\
\hline Plagiarism \\
Indexing \\
History \\
Copyright
\end{tabular}

Articles Cited in

Scopus 
Efektivitas Pemberian Makanan Tambahan (PMT) Pemulihan Pada Status Gizi Balita di Wilayah Kerja Puskesmas Simomulyo, Surabaya

doi

10.20473/amnt.v4i1.2020.58-64

Arum Sekar Rahayuning Putri, Trias Mahmudiono 5 Surabaya

doi 10.20473/amnt.v4i1.2020.65-71

Winda Kusumawardani, Farapti Farapti

Hubungan Sumber Informasi dan Pengalaman dengan Tingkat Pengetahuan tentang Penggunaan Monosodium Glutamate (MSG) pada Ibu Rumah Tangga

doi 10.20473 /amnt.v4i1.2020.72-78

Yasmin Muntaza, Annis Catur Adi

Hubungan antara Aktivitas Fisik dan Aktivitas Sedentari dengan Status Gizi Lebih pada Anak Sekolah Dasar

doi

10.20473/amnt.v4i1.2020.79-84

Erlina Nurlaili Rahma, Bambang Wirjatmadi
Hubungan Perilaku Diet Dengan Massa Lemak Tubuh Pada Remaja Putri Di SMA Negeri

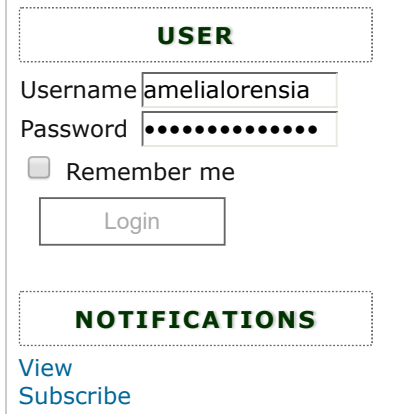

TOOLS:
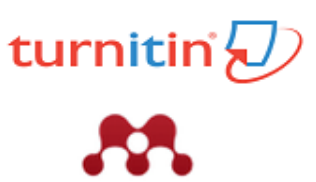

MENDELEY

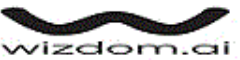

in collaboration with:

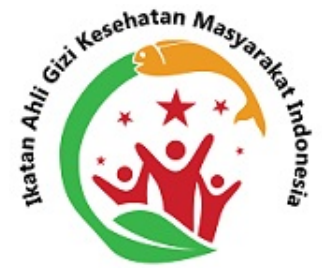

LISTED in:

AmertaNutr

INDEXING BY: $\square \bigwedge \int \begin{aligned} & \text { DIRECTORY OF } \\ & \text { OPEN ACCESS } \\ & \text { JOURNALS }\end{aligned}$

CSÎta EBSCO

AMERTA NUTR by Unair is licensed under a Creative Commons Attribution-ShareAlike 4.0 International License.

p-ISSN : 2580-1163

e-ISSN : 2580-9776

08241254

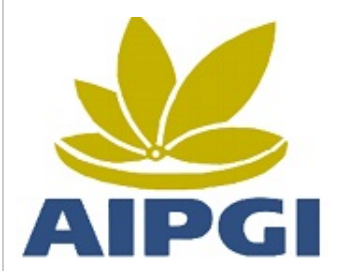

‘ublons

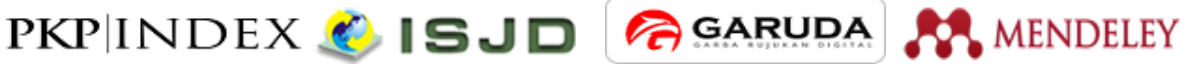

ROAD@Scilit JournalTocs @ CNKI

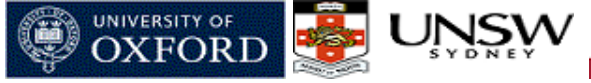

Boston University Libraries OpenBU

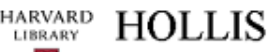
M. Uninesileit
Lancaster University

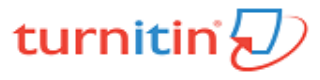

JOURNAL CONTENT

Search

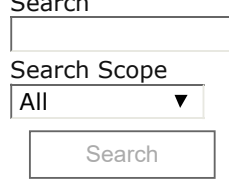

Browse

By Issue

By Author

By Title

Other Journals 
amino acid, citrulline, sport nutrition, sport performance, athletes anemia anemia, enhancer, inhibitor, zat besi attitude children children, nutrient intake, stunting dietary diversity energy intake food intake, weekend, weekday, obesity free radical, COPD, inflammation, cigarette smoke hemoglobin level infectious disease knowledge mother's knowledge, mother's education, exclusive
breastfeeding, infants aged 6-12

months nutritional status personal education, lecture, knowledge level, packaged food choice, nutrition facts label protein intake

stunting toddler underweight zinc

Pusat Pengembangan Jurnal dan Publikasi IImiah

Universitas Airlangga

copyright@2017 Template PPJPI 